\title{
O NARRADOR MACHADIANO: QUINCAS BORBA
}

Sérgio Alves Peixoto Universidade Federal de Minas Gerais

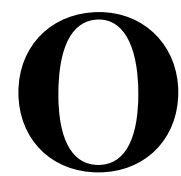

narrador é o que há de mais importante em qualquer narrativa. É ele quem dá as cartas ao leitor: pode mostrálas todas de uma vez, pouco a pouco, ou escondê-las durante todo o tempo que achar necessário. Não podemos nada contra ele. Não adianta acharmos que poderia ter sido mais claro ou menos falastrão: a história a ser contada a ele pertence e é a ele que cabe a decisão de encontrar a maneira mais adequada - ou a mais ardilosa - de apresentá-la ao leitor.

No que diz respeito a Machado de Assis, principalmente nos romances da chamada segunda fase, como é o caso de Quincas Borba, o narrador faz questão de mostrar-se, esmerando-se no artifício de tornar-se uma espécie de personagem de sua própria narrativa. Diferentemente de Flaubert, que preferiu quase que compulsivamente escondê-lo, o narrador em Machado dá sempre os ares de sua graça, principalmente através dos constantes apelos que faz diretamente ao leitor, buscando trazê-lo para a narrativa, tornando-o, também, uma espécie de personagem a quem a todo momento é lembrado de que pode tudo observar, tudo saber, mas que, de forma alguma, poderá alterar os fatos. Essa espécie de "narrador sádico e perverso" que se intromete sistematicamente na narrativa para, entre outras coisas, incomodar seu leitor, é o artifício preferido de Machado para fazer com que esse leitor dela participe. Assim fazendo, caminham ambos em um mundo de ambigüidades, perdem-se ambos em devaneios e digressões, vivem, como 
cúmplices, as dúvidas e os sofrimentos dos personagens, do leitor e do próprio narrador. E nessa conversa íntima entre o narrador e o leitor, aquele sente-se à vontade para criticá-lo, chamando-o de curioso, apressado, mal-intencionado, fofoqueiro. Ao longo de toda a narrativa de Quincas Borba, isso pode ser visto, como nos mostram os exemplos que se seguem:

Queres o avesso disso, leitor curioso? Vê este outro convidado para o almoço, Carlos Maria. (Capítulo 31)

Não, senhora minha, ainda não acabou este dia tão comprido; não sabemos o que se passou entre Sofia e Palha, depois que todos se foram embora. [...] Tende paciência; é vir agora outra vez a Santa Teresa... (Capítulo 50)

Oh! precaução sublime e piedosa da natureza, que põe uma cigarra viva ao pé de vinte formigas mortas para compensá-las. Essa reflexão é do leitor. Do Rubião não pode ser. (Capítulo 90)

E Sofia? interroga impaciente a leitora, tal qual Orgon: Et Tartufe? Ai, amiga minha, a resposta é naturalmente a mesma, - também ela comia bem, dormia largo e fofo, - cousas que, aliás, não impedem que uma pessoa ame, quando quer amar. Se esta última reflexão é o motivo secreto da vossa pergunta, deixai que vos diga que sois muito indiscreta, e que eu não me quero senão com dissimulados. (Capítulo 138)

Há muitos mais exemplos dessas conversas com o leitor, mas seria desnecessário e, principalmente, enfadonho enumerá-los todos aqui. O importante é saber-se que, nesses diálogos íntimos, a narrativa é examinada, explicada, contestada; o narrador desmascarado, e o leitor idem. O próprio método escolhido pelo narrador para contar a historia do "nosso amigo" Rubião é posto em questão no romance, como podemos ver nos capítulos 112, 113 e 114, capítulos que, embora bastante curtos, são importantíssimos, e que, por isso mesmo, serão, aqui, reproduzidos por inteiro:

Aqui é que eu quisera ter dado a este livro o método de tantos outros, - velhos todos, - em que a matéria do capítulo era posta no sumário: "De como aconteceu isto assim e mais assim". Aí está Bernardim Ribeiro; aí estão outros livros gloriosos. Das línguas estrangeiras, sem querer subir a Cervantes nem a Rabelais, bastavam-me Fielding e Smollet, 
muitos capítulos dos quais só pelo sumário estão lidos. Pegai em Tom Jones, livro IV, cap.I, lede este título: Contendo cinco folhas de papel. É claro, é simples, não engana a ninguém; são cinco folhas, mais nada, quem não quer não lê, e quem quer lê, para os últimos é que o autor conclui obsequiosamente: "E agora, sem mais prefácio, vamos ao seguinte capítulo." (Capítulo 112)

Se tal fosse o método deste livro, eis aqui um título que explicaria tudo: "De como Rubião,. satisfeito da emenda feita no artigo, tantas frases compôs e ruminou, que acabou por escrever todos os livros que lera".

Lá haverá leitor a quem só isso não bastasse. Naturalmente, quereria toda a análise da operação mental do nosso hoem, sem advertir que, para tanto, não chegariam as cinco folhas de papel de Fielding. Há um abismo entre a primeira frase de que Rubião era co-autor até a autoria de todas as obras lidas por ele; é certo que o que mais lhe custou foi ir da frase ao primeiro livro; - deste em diante a carreira fez-se rápida. Não importa; a análise seria ainda assim longa e fastiosa. O melhor de tudo é deixar só isto; durante alguns minutos, Rubião se teve por autor de muitas obras alheias. (Capítulo 113)

Ao contrário, não sei se o capítulo que se segue poderia estar todo no título. (Capítulo 114)

O modo de narrar machadiano já foi pejorativamente chamado, por Sílvio Romero, crítico contemporâneo do autor, de um "perpétuo tartamudear". No Brasil, Sílvio Romero é um dos pontos máximos da crítica científico-determinista tão em voga no século XIX, crítica essa bebida principalmente em Taine e Comte. Mas isso não quer dizer grande coisa. Sua grandiosa História da literatura brasileira é, sem dúvida, muito importante para o estudo da cultura e do homem brasileiros de seu tempo; mas quando o crítico se detém em analisar as obras literárias propriamente ditas, o resultado não é dos melhores, e pouca coisa resta. Não porque os princípios em que se baseou estejam hoje totalmente desatualizados, mas porque os levou ao radicalismo determinista. Querendo explicar Machado, por exemplo, Sílvio Romero reduz seu estilo à simples resultante biológica de uma gagueira, esse "tartamudear" de que já falamos: 
O estilo de Machado de Assis, sem ter grande originalidade, sem ser notado por um forte cunho pessoal, é a fotografia exata do seu espírito, de sua índole psicológica indecisa. [...] Vê-se que ele apalpa e tropeça, que sofre de uma perturbação qualquer nos órgãos da palavra[...].

Realmente, Machado de Assis repisa, repete, torce, retorce tanto suas idéias e as palavras que as vestem, que deixa-nos a impressão de um perpétuo tartamudear. Esse veso, esse sestrim para muito espírito subserviente tomado por uma coisa consciensiosa-mente praticada, elevado a uma manifestação de graça e humor, é apenas, repito, o resultado de uma lacuna do romancista nos órgãos da palavra. ${ }^{1}$

Sílvio Romero não conseguia compreender um narrador diferente dos que via nos romances naturalistas e realistas de sua época, preocupados em representar, quase sempre denunciando, uma realidade que, para Machado, sempre se apresentava como, no mínimo, ambígua. Poesia, romance, conto, teatro, política, tudo Sílvio Romero abarcou com sua imensa capacidade de crítico mais interessado na construção de uma determinada mentalidade brasileira do que exatamente na literatura. Pena que os postulados científico-positivistas de que se valeu, e em que acreditava cegamente, obnubilassem, para usarmos uma das palavras-chave da crítica determinista do século XIX, sua visão estética, que já não era muita. Dessa maneira, o narrador machadiano se confundia, para ele, com o homem Machado, e a obra do escritor aparecia como conseqüência natural, mecânica e patológica de uma deficiência orgânica e psíquica.

Modernamente, e agora como alto elogio, Roberto Schwarz chama o narrador machadiano de narrador "volúvel". ${ }^{2}$ O tartamu-

${ }^{1}$ ROMERO, Sílvio. Machado de Assis, p.81-83.

${ }^{2}$ SCHWARZ, Roberto. Um mestre na periferia do capitalismo-Machado de Assis. Trata-se de um livro que procura aliar uma crítica sociológica a uma preocupação sempre presente com o romance como um produto estéticoformal. O "narrador volúvel" de que fala Schwarz, analisando as Memórias póstumas de Brás Cubas, é marca de todos os romances machadianos, principalmente os da chamada segunda fase. 
dear e a volubilidade do narrador em Machado é realmente sua marca registrada, e marca registrada, também, de uma modernidade que ele antecipou, e que Schwarz procura ressaltar.

Por ser volúvel, o narrador machadiano não é digno de confiança. Por tartamudear, conduz-nos em uma espécie de labirinto de que desejamos encontrar a saída sempre negaceada. Se verdadeiramente não engana o leitor, deixa-o muitas vezes acreditar no que diz, para, logo em seguida, ou, bem mais tarde, quando ele pensa estar tudo compreendendo, retomar os fatos narrados em capítulos inesperadamente surpreendentes a fim de mostrar as possíveis contradições e ambigüidades que encerram. Ou vice-versa: atribui ao leitor as dúvidas, as desconfianças, as indecisões, quase sempre criticando-o por sua preguiça ou por sua falta de atenção em segui-lo no seu tartamudear e na sua volubilidade. Lembram-se do capítulo 89, no qual Rubião acredita ter Sofia e Carlos Maria marcado um encontro adúltero em uma casa da rua da Harmonia (perceberam a ironia, e não a mera coincidência, como dirá em determinado momento da narrativa, na escolha do nome da rua?) É a este capítulo que se refere o de número 106. O que no capítulo 89 foi-nos apresentado como verdade (Sofia era amante de Carlos Maria) passa a ser visto, agora,como coincidência, acaso, fantasia, leitura apressada e desatenta, ciúmes do Rubião, invenções de um reles cocheiro:

...ou mais propriamente, capítulo em que o leitor desorientado, não pode combinar as tristezas de Sofia com a anedota do cocheiro. E pergunta confuso: - Então a entrevista da rua da Harmonia, Sofia, Carlos Maria, esse chocalho de rimas sonoras e delinqüentes é tudo calúnia? Calúnia do leitor e do Rubião, não do pobre cocheiro, que não proferiu nomes, não chegou sequer a contar uma anedota verdadeira. É o que terias visto, se lesses com pausa. Sim, desgraçado, adverte bem que era inverossímel; que um homem, indo a uma aventura daquelas, fizesse parar o tílburi diante da casa pactuada. Seria pôr uma testemunha ao crime. Há entre o céu e a terra muitas mais ruas do que sonha a tua filosofia, - ruas transversais, onde o tílburi podia ficar esperando. 
- Bem; o cocheiro não soube compor. Mas que interesse tinha em inventar a anedota?

Conduzira Rubião a uma casa, onde o nosso amigo ficou quase duas horas, sem o despedir; viu-o sair, entrar no tílburi, descer logo e vir a pé, ordenando-lhe que o acompanhasse. Concluiu que era ótimo freguês; mas, ainda assim não se lembrou de inventar nada. Passou, porém, uma senhora com um menino, - a da rua da Saúde, - e Rubião quedou-se a olhar para ela com vistas de amor e melan-colia. Aqui é que o cocheiro o teve por lascivo, além de pródigo, e encomendoulhe as suas prendas. Se falou em rua da Harmonia foi por sugestão do bairro donde vinham; e, se disse que trouxera um moço da rua dos Inválidos, é que naturalmente transportara de lá algum, na véspera, talvez o próprio Carlos Maria, - ou porque lá morasse, - ou porque lá tivesse cocheira, - qualquer outra circunstância que lhe ajudou a invenção, como as reminiscências do dia servem de matéria aos sonhos da noite. Nem todos os cocheiros são imaginativos. Já é muito concertar farrapos da realidade.

Resta só a coincidência de morar na rua da Harmonia uma das costureiras do luto. Aqui, sim, parece um propósito do acaso. Mas a culpa é da costureira; não lhe faltaria casa mais para o centro da cidade, se quisesse deixar a agulha e o marido. Ao contrário disso, ama-os sobre todas as coisas deste mundo. Não era razão para que eu cortasse o episódio, ou interrompesse o livro.

Se o cocheiro não soube "compor" sua história, o narrador de Quincas Borba sabe-o muito bem. Seu método não é o mais comum, mas é bem engenhoso e mesmo maquiavélico. O "tartamudear", de que nos fala Sílvio Romero, faz com que a narrativa seja retardada pelas digressões que tornam o ritmo lento, a fim de que narrador e leitor possam "ruminar" as questões levantadas por personagens complexos, profundos e ambíguos, mesmo que, muitas vezes, pareçam ser superficiais e frívolos. As análises assumem um papel preponderante: análises psicológicas, na sua maioria, mas também análises de questões sociais, políticas e históricas, como acontece, mesmo que aparentemente de modo também superficial, com os desmandos da Guerra do Paraguai, com as questões escravagistas, ou com os problemas do reinado de D. 
Pedro II, tudo, na verdade, não mero pano de fundo, mas o próprio palco (nunca bem iluminado) em que transitam os seres de Machado. Trata-se de um método bem particular, como, ironicamente, diz o narrador que deveria haver também um método na loucura de Rubião, personagem principal do romance, loucura essa tema central da narrativa. Pouco a pouco apresentada, desenvolvida com certa lentidão e, ao final, acelerada, como se nada mais houvesse a dizer sobre ela, a narrativa da insanidade de Rubião corre mais rápida tão logo a loucura se instala definitivamente no cérebro do pobre e ingênuo interiorano. Assim nos diz o narrador no capítulo 109, comentando a identificação de Sofia com a imperatriz Eugênia, mulher de Napoleão III, personagem histórico que Rubião "incorpora" em seus delírios de soberba e miséria:

Mas eu prefiro a reflexão do velho Polonius, acabando de ouvir uma fala tresloucada de Hamlet: "Desvario embora, lá tem seu método". Também há método aqui, nessa mistura de Sofia e Eugênia; e ainda há método no que se lhe seguiu, e que parece mais extravagante.

Com seu método tartamudeante, o volúvel narrador de Quincas Borba exorta ironicamente os leitores, no último capítulo do romance, a decidirem pelas lágrimas ou pelo riso. Ironicamente, porque, logo em seguida, nos diz que, no céu, as estrelas - ou, metaforicamente, o próprio Deus - pouco se importam com a felicidade ou a infelicidade humanas. Sofia, também não. E nós, quem sabe, muito menos, porque, ao fim e ao cabo, tudo não passa de ficção:

Queria dizer aqui o fim do Quincas Borba, que adoeceu também, ganiu infinitamente, fugiu desvairado em busca do dono, e amanheceu morto na rua, três dias depois. Mas, vendo a morte do cão narrada em capítulo especial, é provável que me perguntes se ele, se o seu defunto homônimo é que dá o título ao livro, e porque antes um que outro, questão prenhe de questões, que nos levariam longe... Eia! chora os dous recentes mortos, se tens lágrimas. Se só tens riso, ri-te! É a mesma cousa. O Cruzeiro, que a linda Sofia não quis fitar, como lhe pedia Rubião, está asssaz alto para não discernir os risos e as lágrimas dos homens. 


\section{Referências Bibliográficas}

ROMERO, Ś́lvio. Machado de Assis. Rio de Janeiro: Laemmert, 1879.

SCHWARZ, Roberto. Um mestre na periferia do capitalismoMachado de Assis. São Paulo: Duas Cidades, 1990.

\section{Resumo}

Considerações sobre o narrador machadiano, a partir do romance Quincas Borba de Machado de Assis

\section{Résumé}

Quelques réflexions sur le rôle du narrateur dans le roman Quincas Borba, de Machado de Assis 